The Review of Finance and Banking

print ISSN 2067-2713, online ISSN 2067-3825

Volume 11, Issue 1, Year 2019

http://dx.doi.org/10.24818/rfb.19.11.01.03, Pages 24-36

\title{
PETROLEUM SUBSIDY AND ITS IMPACT ON TAX REVENUE VOLATILITY
}

\author{
MATTHEW O. GIDIGBI, KEHINDE M. BELLO, AND GBENGA F. BABARINDE
}

\begin{abstract}
Energy pricing did not only have an implication on the indigent but on the national government as well. Petroleum subsidy tolerance impacts the government revenue of certainty but the extent of its impact needs to be determined. Therefore, it becomes imperative to assess the contribution of the petroleum subsidy on tax volatility. Data were sourced from the NNPC Annual Statistical Bulletin (ASB) for the year 1997, 2005, 2008 and 2016; Central Bank of Nigeria (CBN) Statistical Bulletin and Statement of Accounts and Annual Reports. An exploratory analysis was conducted on extracted data to generate other variables of interest such as subsidy on premium motor spirit, tax revenue volatility before proceeding to Lease Squares analyses. ARCH and GARCH models were applied to ascertain the volatility of tax revenue. Petroleum subsidy positively impacts tax revenue volatility; the impact was minimal but statistically significant at 1 per cent significance level. Exchange rate increased the tax revenue volatility by 5.10 point in the long-run, likewise gross domestic savings by 0.4 point in the long-run and both estimates were statistically significant at 1 per cent respectively. Both government expenditure and gross fixed capital formation reduced the tax revenue volatility at 0.05 and 0.03 point respectively and the estimates were statistically significant at 10 per cent and 1 per cent. The ECM showed that any deviation in the estimates would be restored within a year and this is statistically significant at 1 per cent. It was therefore recommended that the government should do more to manage and maintain appropriate exchange rate policy and keep up improving on its expenditure towards capital formation and investment in order to manage tax revenue volatility.
\end{abstract}

\section{INTRODUCTION}

The fuel subsidy in Nigeria gulped government revenue in different ways, from what is expended as subsidy payment to the tax loss. More so, tax revenue is used to fill any financial tightness created by diverting financial resources towards payment of subsidy. Although, the subsidy is deducted from what the Nigerian National Petroleum Corporation (NNPC) is to remit to the national government. It, however, collapsed what would have been an additional fiscal space that the government would have gotten or enjoyed. In the plain term, the government lost fiscal space due to the subsidy. In addition, tax revenue variability is known to complicate state budgeting proceedings. In the past years, the government had not enjoyed the targeted alternative forgone for this loss of fiscal space which equally translates to tax revenue volatility. The government's target of providing more welfare for the teeming population through subsidy failed woefully; as the indigence failed to get the intended welfare and the subsidy scheme was flooded with an avalanche of malpractice at the detriment of the masses and the government

Received by the editors May 31, 2019. Accepted by the editors June 27, 2019.

Keywords: Petroleum, Subsidy, Tax Revenue, Volatility, Exchange Rate, ARCH and GARCH..

JEL Classification: C22, F31, H20, Q43.

Matthew O. Gidigbi, Department of Economics, Modibbo Adama University of Technology, Nigeria. E-mail: gidigbimd@mautech.edu.ng.

Kehinde M. Bello, Department of Economics, Obafemi Awolowo University, Nigeria. E-mail: kennybello2008@gmail.com.

Gbenga F. Babarinde, Department of Banking and Finance, Modibbo Adama University of Technology, Nigeria. E-mail: liftedfgb@gmail.com.

This paper is in final form and no version of it will be submitted for publication elsewhere. 
revenue. Petroleum or Premium Motor Spirit (PMS) subsidy scheme in Nigeria was plagued with serious allegations of manipulation, such that the actual landed amounts of fuel have been different from those recorded, to facilitate excessive subsidy claims (McCulloch \& Okigbo-III, 2015). Thus, this paper investigates the impact of PMS subsidy on tax revenue volatility in Nigeria.

Rueben and Randall (2017) asserted that revenue volatility would be caused by the following reasons: taxes sensitivity, dipping energy prices, and the dependency of states among others. The structure of energy prices equally affected tax revenue volatility. Not only that subsidy causes tax revenue volatility but equally impact the general macroeconomic variables. Its impact on tax revenue volatility is only one of its effects on the macroeconomic parameters. The subsidy has macroeconomic, environmental and social implications. It has an adverse effect on economic growth, which transcends beyond fiscal balances and public debt (Rogoff \& Reinhardt, 2010). It crowds out investment because low and subsidized prices can result in lower profits or outright losses of investors (IMF, 2013). Also, it crowds out growth-enhancing public spending such as the case of Nigeria where the subsidy amounted to 2-5 times the size of the federal education budget and 7 times the health budget (McCulloch \& Okigbo-III, 2015). Subsidy gives room for smuggling, and divert public resources away from spending that is more pro-poor (IMF, 2013). The subsidy, as it concerns the environment, leads to overconsumption, which resulted in higher $\mathrm{CO} 2$ emission. In a nutshell, it promotes global warming and air pollution.

World Bank, (2010) asserted that subsidy can be financed through taxes, cross-subsidies, cuts in other expenditure, borrowing or tax expenditures. It furthered by clarifying the subsidies arrangement to the following categories: explicit, implicit, and cross-subsidies. Explicit subsidies mean direct transfer to the producer or consumer that is receiving the subsidy from the government budget. Such is the case in Nigeria because there was always subsidies provision in the budget. The implicit subsidy comes to play when there is no immediate transfer from the government. It may mean the budget provision did not cover subsidy at a time; this may necessitate public borrowing to cover up (World Bank, 2010). It is rightly said that someone must pay for a subsidy, is either government or its citizens through taxes. Even when the government pays, it is still from the resources that would have been used for possibly pro-poor spending; therefore, the citizens still pay indirectly.

Taxes lost to subsidy are on dual ends, pre-tax subsidy and post-tax subsidy. Pre-tax subsidies imply pricing of energy below private cost that is relative to efficient prices excluding any Pigouvian tax to address externalities; and post-tax subsidies imply pricing of energy below the social cost that is relative to efficient prices including a Pigouvian tax (Davis, 2017). Mostly post-tax is found to be greater than the pre-tax (Davis, 2017; IMF, 2013). Parry, (1998) asserted that expenditures in form of the subsidy must be financed through taxes, which implies that tax revenue will experience ups and downs depending on the quantum of financial resources that go to the subsidy. IMF, (2013) observed that energy subsidies are pervasive and impose substantial fiscal and economic costs. It further observed that 0.7 per cent of global GDP or 2 per cent of total government revenues, which sum up to $\$ 450$ billion in 2011 was subsidized on a pre-tax basis. On the other hand, post-tax energy subsidies were estimated at $\$ 1.9$ trillion in 2011, which is about 2.5 per cent of global GDP or 8 per cent of total government revenue (IMF, 2013). Unfortunately, when the government gives subsidy on fuel, there is a high tendency that such would not border to factor in post-tax, especially, in the developing countries where subsidies override both pre-tax and post-tax prices. Considering the administration of subsidy in Nigeria, it was certain that tax revenue volatility is inevitable like any other country, especially, the developing countries.

\section{DATA DESCRIPTION AND METHODOLOGY}

2.1. Research Design and Sources of Data. This paper examines the causal relationship between PMS subsidy and the volatility of tax revenue, thereby, a quantitative method of 
analysis was applied. Data ${ }^{1}$ used for the analysis is time-series data covering the period of 1981 to 2016, that is, the period of thirty-six (36) years. The data were sourced from the Nigerian National Petroleum Corporation (NNPC) Annual Statistical Bulletins (ASB) for the year 1997, 2005, 2008 and 2016 editions; Central Bank of Nigeria (CBN) Statistical Bulletin 2017 edition and Statement of Accounts and Annual Reports for various years. Data on tax revenue, government expenditure, exchange rate, gross domestic savings and gross fixed capital formation were sourced from the CBN Statistical Bulletin 2017 edition; Petrol (Premium Motor Spirit [PMS]) subsidy was calculated from data extracted from the NNPC Annual Statistical Bulletin (ASB) for the year 1997, 2005, 2008 and 2016 editions, using historical PMS prices as compiled by Adagunodo, (2013); and pre-reform and post-reform subsidy benchmark as a percentage of the fuel price as cited in Atansah, Khandan, Moss, Mukherjee and Richmond, (2017).

Finally, this study has become the pathfinder in providing a fully empirical study on context bordering on PMS Subsidy in Nigeria. It is so because there was no database for PMS subsidy in Nigeria up till the time this study was carried out but the study has taken time to estimate PMS subsidy based on the available information about the domestic quantity of PMS used in the country, market prices and the landing costs. These three variables were sourced from different sources stated in the earlier paragraph and the PMS subsidy was calculated from them, following the design template for the subsidy calculation in Nigeria.

2.2. Model Specification: Table 2.2.1 shows the definition of variables used in the study, starting from the model specification to the analysis, these set of variables defined were used all through.

\begin{tabular}{|l|l|}
\hline \multicolumn{2}{|c|}{ Table 2.2.1: Variable Definitions } \\
\hline TRV5 & Tax Revenue at 5 years standard deviation point calculation \\
\hline PMS_SUB & PMS Subsidy \\
\hline GTEXP & Government Expenditure \\
\hline EXCR & Exchange Rate \\
\hline GFCF & Gross Fixed Capital Formation \\
\hline GDS & Gross Domestic Savings \\
\hline ECM & Error Correction Model at lagged 1 \\
\hline U & Error Term \\
\hline$\alpha$ & Intercept \\
\hline $\mathrm{t}$ & Time trend \\
\hline \multicolumn{2}{|c|}{ Source: Authors' Compilation $(2018)$} \\
\hline
\end{tabular}

First and foremost, a model to test tax revenue volatility was specified, before the study proceeded into the main estimation of the specified model in equation 2. ARCH and GARCH estimation was used to model the volatility of the variable.

Equation 1: ARCH and GARCH Estimation Model for Volatility Testing

$$
\text { Var of } T R V 5_{t}^{2}=\omega+\alpha \epsilon_{t-1}^{2}+\beta \sigma_{t-1}^{2}
$$

The simplest GARCH of one lag one $(1,1)$ was specified. The paper does not bother about the means equation in the estimation but focuses on the variance equation as the study took a decision based on the variance equation. The variance of the tax revenue using five period's basis calculation is the one-period-ahead forecast variance based on past information, which is equally referred to as conditional variance. The first parameter in the RHS of equation 1 is the constant in the model, and the second part in the same side measured volatility from the previous period, which is captured as the lag of the squared residuals from the mean equation

\footnotetext{
${ }^{1}$ Dataset used for the analysis is deposited in this address: http://dx.doi.org/10.17632/cbb825g3r7.1.
} 
(that is the ARCH estimator), while the third part in the same side is the last period's forecast variance (that is the GARCH term).

Equation 2: Long-Run Model between Tax Revenue Volatility and PMS Subsidy as the major control variable

$$
T R V 5_{t}=\alpha_{0}+\beta_{1} P M S_{-} S U B_{t}+\beta_{2} G T E X P_{t}+\beta_{3} E X C R_{t}+\beta_{4} G D S_{t}+\beta_{5} G F C F_{t}+\mu_{t}
$$

Equation 3: Short-Run Model between Tax Revenue Volatility and PMS Subsidy as the major control variable

$$
\begin{aligned}
D(T R V 5)_{t}= & \alpha_{0}+\beta_{1} D\left(P M S_{-} S U B\right)_{t}+\beta_{2} D(G T E X P)_{t}+ \\
& \beta_{3} D(E X C R)_{t}+\beta_{4} D(G D S)_{t}+\beta_{5} D(G F C F)_{t}+E C M(-1)+\mu_{t}
\end{aligned}
$$

The inclusion of all these variables in the model is appropriate because it was clearly noted that fuel subsidy has implication for macroeconomic variables (IMF, 2013; World Bank, 2010). Theoretical expectations (a priori) for the model in equation 2 and 3 are as follows: Premium Motor Spirit subsidy (PMS_SUB) estimate is expected to have a positive relationship with tax revenue volatility $\left(\beta_{1}>0\right)$ because it crowds out investment in both the long-run and shortrun. Government expenditure (GTEXP) is expected to reduce tax revenue volatility $\left(\beta_{2}<0\right)$ because it promotes consumption, which resulted in consumption taxes on a part. Exchange rate (EXCR) is expected to exhibit a positive relationship $\left(\beta_{3}>0\right)$ because its depreciation would increase tax revenue volatility while its appreciation would do otherwise. Gross domestic savings (GDS) is expected to increase tax revenue volatility $\left(\beta_{4}>0\right)$ because when savings increases disposable income, consumption declines and thereby declines tax revenue as well. Gross fixed capital formation (GFCF) is expected to contribute negatively to tax revenue volatility because the more investment in a country, the more taxable productive activities to be carried out.

Majorly, the following tests, unit-root test and cointegration test were carried out before the estimation of equation 1,2 and 3. The unit-root test helps to ascertain the stationarity of the dataset since the data structure is time-series in nature, it has the tendency of walking randomly. Also, the cointegration test was carried out to ascertain the existence of a long-run relationship among the specified variables and be sure that the specified long-run model can be estimated.

2.3. Stationarity Test. The test was carried out before the estimation of the specified model. Augmented Dickey-Fuller (ADF) and Phillips-Perron (PP) tests were employed. Testing the stationarity of the data becomes imperative in order not to estimate spurious regressions, which implies significant coefficients without a long-run relationship. The test was performed at the level and beyond but only the stage at which each of the variables exhibited stationarity was reported. ADF was used at first but where an ideal result was not obtained, PP test was applied because it is more powerful than ADF due to its relaxation of homoscedasticity assumption, and thus it works better in the presence of heteroskedasticity (Hamilton, 2006).

$$
\begin{aligned}
\Delta y_{t} & =\alpha_{0}+\gamma y_{t-1}+\sum_{j=2}^{\beta} \beta_{j} \Delta y_{t-j}+\varepsilon_{t}, \text { where } \varepsilon \sim \operatorname{IID}\left(0, \sigma^{2}\right) \\
H_{0} & : \quad \gamma=0 \text { (nonstationary, i.e. presence of unit root) } \\
H_{1} & : \quad \gamma<0 \text { (stationary, i.e. no presence of unit root) }
\end{aligned}
$$


Where: $y$ in the equation represent each of the variables in the specified model; $\varepsilon$ is the error term; $\gamma$ is the stationarity coefficient; $\alpha_{0}$ and $\beta_{j}$ are parameters to be estimated.

2.4. Cointegration Test. Johansen and Juselius cointegration test was used to assess the existence of a long-run relationship among the variables. If at all the variables involved are not stationary at levels, then the variables involve will be differenced so that their linear combination will cancel out the stochastic trends in them (Johansen, 1991).

\section{RESULTS AND DISCUSSION}

This section presents the estimation outputs in the order of estimation and discusses the outputs as necessary. It showed the descriptive statistics, stationarity test, cointegration test and least square test for both long-run and short-run estimations. In addition, other relevant statistics in graphical form was included to buttress the reliability and stability of the model estimated in both cases.

3.1. Descriptive Statistics. Table 3.1 shows the descriptive statistics of the variables in the specified model, which are measured in the same unit. These are the definition of the variables in the table 3.1: Tax Revenue at 5 years Standard Deviation Point calculation (TRV5); PMS Subsidy (PMS_Sub); Government Expenditure (GTEXP); Exchange Rate (EXCR), which is the equivalent of US\$ 1 to Naira ${ }^{2}$; Gross Domestic Saving (GDS); and Gross Fixed Capital Formation (GFCF). The unit of measurement of each variables is in Billion of Naira (Naira'B) with the exception of Exchange Rate, which is in Naira (from unit to hundredth). The JargueBera's probability value actually refute the even distribution (normality) of the Petroleum or Premium Motor Spirt Subsidy (PMS_SUB), Government Expenditure (GTEXP), Gross Domestic Savings (GDS) and Gross Fixed Capital Formation (GFCF). However, the t-statistics and F-statistics from the analysis will not be misleading following the Central Limit Theorem (CLT), which asserted that when an observation set is 30 and above, it is assumed to be normally distributed. Thereby, the study continues with its estimation having the assurance that the test statistics would not be misleading in taking decision irrespective of Jarque-Bera's statistics. Less attention is given to the maximum and minimum values towards data cleaning, since, the data is from the emerging economy.

\begin{tabular}{|l|c|c|c|c|c|c|}
\hline \multicolumn{7}{|c|}{ Table 3.1: Descriptive Statistics } \\
\hline & TRV5 & PMS_SUB & GTEXP & EXCR & GDS & GFCF \\
\hline & (Naira'B) & $($ Naira'B $)$ & $($ Naira'B $)$ & $($ Naira $)$ & (Naira'B) & $($ Naira'B) \\
\hline Mean & 393.2834 & 11114.40 & 1421.473 & 79.31887 & 2166.056 & 2335.765 \\
\hline Median & 113.0615 & 85.92449 & 487.1134 & 57.37221 & 706.5915 & 41.13860 \\
\hline Maximum & 1533.200 & 87903.49 & 5185.318 & 305.0000 & 15368.02 & 14135.66 \\
\hline Minimum & 1.652406 & 0.517849 & 9.636500 & 0.610025 & -67.13813 & 6.331640 \\
\hline Std. Dev. & 446.2737 & 24177.49 & 1768.143 & 77.46510 & 3568.873 & 4802.533 \\
\hline Skewness & 0.835888 & 2.134244 & 1.047196 & 0.694883 & 2.423742 & 1.667920 \\
\hline Kurtosis & 2.643966 & 6.252046 & 2.560265 & 2.900845 & 8.209793 & 3.973733 \\
\hline Jarque-Bera & 4.382394 & 43.19369 & 6.678935 & 2.911918 & 65.41006 & 18.11397 \\
\hline Probability & 0.111783 & 0.000000 & 0.035456 & 0.233177 & 0.000000 & 0.000117 \\
\hline Observations & 36 & 36 & 35 & 36 & 31 & 36 \\
\hline \multicolumn{7}{|c|}{ Source: Authors' computation using Eviews 10} \\
\hline
\end{tabular}

\footnotetext{
${ }^{2}$ Naira is the Nigeria official national currency denomination. 100 Kobos make One Naira.
} 
3.2. Unit-Root Tests. The unit root test results summarized in table 3.2 shows that all the variables are not stationary at level but at the induced level of one. Thereby, there is a need to test for the existence of a long-run relationship in order to override any possible chances of running a nonsensical regression. The ECM variable is a residual of all the variable of interest when estimated as ordinary least squares; residual $\left(u_{t}\right)$ of the specified equation 2 . The ECM variable in the table is stationary at the level, that is the integration of order one $-I(0)$. This implies that the possible random walk (non-stationarity) in the variables cancelled out one another in a long-run estimation. However, the cointegration test was still carried out to further buttress the finding of stationarity of the variables in the specified models.

\begin{tabular}{|l|c|c|c|c|c|}
\hline \multicolumn{7}{|c|}{ Table 3.2: Unit Root Tests } \\
\hline Variable & Test & t-statistics & Prob. & Significance & Order of \\
\hline & statistics & & & Level & integration \\
\hline TRV5 & ADF & -4.061888 & 0.0190 & 1 percent & $\mathrm{I}(1)$ \\
\hline PMS SUB & PP & -2.557022 & 0.0122 & 1 percent & $\mathrm{I}(1)$ \\
\hline GTEXP & PP & -3.515037 & 0.0571 & 5 percent & $\mathrm{I}(1)$ \\
\hline EXCR & PP & -4.684561 & 0.0051 & 1 percent & $\mathrm{I}(1)$ \\
\hline GDS & PP & -7.868253 & 0.0000 & 1 percent & $\mathrm{I}(1)$ \\
\hline GFCF & PP & -5.810288 & 0.0002 & 1 percent & $\mathrm{I}(1)$ \\
\hline ECM & ADF & -5.054058 & 0.0059 & 1 percent & $\mathrm{I}(0)$ \\
\hline \multicolumn{7}{|l|}{ Source: Authors' computation using Eviews 10 } \\
\hline
\end{tabular}

3.3. Cointegration Estimation. Since the unit root tests suggested a further test for a longrun relationship if at all the variables in the specified model can be pulled together for reasonable estimation. Although, the unit-root test of the ECM variable had cleared off the air about that for correctness' sake and as a matter of emphasis, the Johansen cointegration test was adopted and carried out for the test of the existence of a long-run relationship among the variables. The test result in the table 3.3.1 is based on Trace statistic while that of table 3.3.2 is based on maximum eigen value statistic. The test results as shown in tables 3.3.1 and 3.3.2 for the main model indicated the existence of a long-run relationship among the variables in the specified models, which implies the possibility of relating the variables at long-run. Therefore, both the long-run and short-run estimations are possible, as the unrestricted cointegration rank test for both Trace in table 3.3.1 and Maximum Eigenvalue in table 3.3.2 indicated the existence of four (4) cointegrating equation at 0.05 significance level. Based on these outputs, the variables could be pooled together in the long-run.

\begin{tabular}{|l|c|c|c|c|}
\hline \multicolumn{5}{|c|}{ Table 3.3.1: Unrestricted Cointegration Rank Test (Trace) } \\
\hline Hypothesized & & Trace & $\mathbf{0 . 0 5}$ & \\
\hline No. of CE(s) & Eigenvalue & Statistic & Critical Value & Prob. ${ }^{* *}$ \\
\hline None* & 0.999090 & 375.6436 & 95.75366 & 0.0001 \\
\hline At most 1 & 0.952327 & 186.5812 & 69.81889 & 0.0000 \\
\hline At most 2* & 0.917508 & 104.4095 & 47.85613 & 0.0000 \\
\hline At most 3 & 0.566932 & 37.04291 & 29.79707 & 0.0061 \\
\hline At most 4 & 0.350470 & 14.44767 & 15.49471 & 0.0714 \\
\hline At most 5 & 0.098407 & 2.796992 & 3.841466 & 0.0944 \\
\hline Source: Authors' computation using Eviews 10 \\
\hline Trace test indicates 4 cointegrating eqn(s) at the 0.05 level \\
\hline * denotes rejection of the hypothesis at the 0.05 level \\
\hline ** MacKinnon-Haug-Michelis (1999) p-values \\
\hline
\end{tabular}




\begin{tabular}{|l|c|c|c|c|}
\hline \multicolumn{5}{|l|}{ Table 3.3.2: Unrestricted Cointegration Rank Test (Maximum Eigenvalue) } \\
\hline Hypothesized & & Trace & $\mathbf{0 . 0 5}$ & \\
\hline No. of CE(s) & Eigenvalue & Statistic & Critical Value & Prob. $^{* *}$ \\
\hline None* & 0.999090 & 189.0624 & 40.07757 & 0.0001 \\
\hline At most 1* & 0.952327 & 82.17176 & 33.87687 & 0.0000 \\
\hline At most 2* & 0.917508 & 67.36657 & 27.58434 & 0.0000 \\
\hline At most 3* & 0.566932 & 22.59524 & 21.13162 & 0.0309 \\
\hline At most 4 & 0.350470 & 11.65068 & 14.26460 & 0.1245 \\
\hline At most 5 & 0.098407 & 2.796992 & 3.841466 & 0.0944 \\
\hline Source: Authors' computation using Eviews 10 \\
\hline Max-eigenvalue test indicates 4 cointegrating eqn(s) at the 0.05 level \\
\hline * denotes rejection of the hypothesis at the 0.05 level \\
\hline ** MacKinnon-Haug-Michelis (1999) p-values \\
\hline
\end{tabular}

3.4. Volatility Test. The ARCH and GARCH tests were used to test for volatility in tax revenue. The output of the estimation is presented in table 3.4.1. The estimation showed that there is the presence of volatility in tax revenue as suggested by the statistically significant coefficient of $\operatorname{RESID}(-1)^{\wedge} 2$, which is the $\mathrm{ARCH}$ test. In addition, adding the $\mathrm{ARCH}$ and GARCH's coefficients at lag one still sum up to one (1), which buttresses the presence of volatility in the variable, and the $\operatorname{GARCH}(-1)$ coefficient is statistically significant.

\begin{tabular}{|l|c|c|c|c|}
\hline \multicolumn{5}{|c|}{ Table 4.3: Volatility Test on Exchange Rate } \\
\hline Dependent Variable: TRV5 \\
\begin{tabular}{|l|c|c|c|c|}
\hline Variable & Coefficient & Std. Error & z-Statistic & Prob. \\
\hline @SQRT(GARCH) & 0.331932 & 0.118615 & 2.798397 & 0.0051 \\
\hline \multicolumn{5}{|c|}{ Variance Equation } \\
\hline C & 2683.764 & 1435.428 & 1.869660 & 0.0615 \\
\hline RESID(-1)^2 & $1.619495^{* *}$ & 0.786150 & 2.060033 & 0.0394 \\
\hline GARCH(-1) & -0.251435 & 0.088978 & -2.825813 & 0.0047 \\
\hline \multicolumn{5}{|c|}{ Source: Authors' computation using Eviews 10 } \\
\hline
\end{tabular}
\end{tabular}

3.5. Model Estimation. The two specified models in equation 1 and 2 were estimated respectively with their results presented in table 3.5.1 and 3.5.2 for both the long-run and short-run estimates respectively. The results were explained and discussed with their significance.

3.5.1. Long-run Estimates. The ordinary least squares in the table 3.5.1 is the long-run estimation of the model specified in equation 2 while Tax Revenue Volatility (TRV5) is the dependent variable. The model's R-squared suggested that the variables in the model accounted for 97.80 per cent variation in the dependent variable. The model maintained almost the same degree of variation at the change of the degree of freedom, as Adjusted R-squared stands to be 97 per cent. The high F-statistic of 222.63 is statistically significant at 1 per cent which suggested a joint significance of the variables that is the variables can actually be pooled together for estimation. The Durbin-Watson statistic which is above 2 suggested the absence of serial correlation as a rule of thumb.

All the variables were statistically significant at 1 per cent with the exception of government expenditure (GTEXP), which was significant at 10 per cent. The trio of petrol subsidy (PMS_SUB), the exchange rate (EXCR) and gross domestic savings (GDS) were contributing to the tax revenue volatility and the duo of government expenditure (GTEXP) and gross fixed capital formation (GFCF) were reducing it. All the variables performed in consonance to the theoretical expectation (a priori).

As popularly observed from extant studies, Premium Motor Spirit (PMS) subsidy increases tax revenue volatility, although, by infinitesimal amount but statistically relevant at 1 per cent. This finding implies that it is 99 per cent certain that PMS subsidy contributed to the tax revenue volatility. This finding is in consonance with the assertion of (Rueben \& Randall, 
2017) and (World Bank, 2010). Also, the exchange rate and gross domestic savings contributed far more to the tax revenue volatility by 5.10 and 0.04 point as a response to a unit increment in each of them respectively. These findings are statistically significant at 1 per cent respectively. A strong point to note here is that contribution of PMS subsidy to the tax revenue volatility is nothing to compare to other variables contribution. Among the variables captured in this model, the exchange rate is the major contributor to the tax revenue volatility followed by the gross domestic savings.

The output in table 3.5.1 further showed that both the government expenditure (GTEXP) and the gross fixed capital formation (GFCF) reduced tax revenue volatility. These findings were statistically significant at 10 per cent and 1 per cent respectively. These make economic sense because when government spend more, it is expected that consumption component would be boosted and thereby steady or more tax revenue will be generated; as for the GFCF, when capital is invested, it created productivity, which finally leads to consumption and both productivity and consumption generate tax revenue in one or the other. Thereby, a unit increase in the government expenditure will decrease tax revenue volatility by 0.05 point and a unit increase in the gross fixed capital formation will equally reduce tax revenue volatility by 0.03 point. These findings were statistically significant and in consonance with the assertion of Rueben and Randall, (2017) because more investment would create more tax bases, which will translate to more tax revenue.

\begin{tabular}{|l|c|c|c|}
\hline \multicolumn{5}{|c|}{ Table 3.5.1: Long-Run Ordinary Least Squares Estimation } \\
\hline \multicolumn{1}{|c|}{ Variable } & Coefficient & t-statistics & Prob. \\
\hline C & $-47.27130^{*}$ & -2.971150 & 0.0065 \\
\hline PMS_SUB & $5.97 \mathrm{E}-12^{*}$ & 2.580479 & 0.0161 \\
\hline GTEXP & -0.053058 & -1.890970 & 0.0703 \\
\hline EXCR & $5.101942^{*}$ & 11.78732 & 0.0000 \\
\hline GDS & $0.043195^{*}$ & 4.276631 & 0.0002 \\
\hline GFCF & $-0.038434^{*}$ & -3.086406 & 0.0049 \\
\hline R-squared & 0.978035 \\
\hline Adj. R-squared & 0.973642 \\
\hline F-stat & $222.6366^{*}$ \\
\hline Durbin-Watson stat & 2.121986 \\
\hline \multicolumn{4}{|c|}{ Source: Authors' computation using Eviews 10} \\
\hline
\end{tabular}

3.5.2. Short-run and Error Correction Model Estimation. Estimation for the short-run and error correction model (ECM) is presented in table 3.5.2. The short-run estimates referred to the variable impact in a year period and the error correction model referred to what will happen to the variables impact on tax revenue volatility when there is a deviation in the observed behaviour of the variables. The dependent variable in the estimation is differenced tax revenue volatility -D(TRV5). The independent variables accounted for 74.95 per cent variation in the dependent variable. Adjusting the degree of freedom would change the R-squared to 68.11 per cent. The F-statistic of 10.97 implied jointly significant of the variables in the model at 1 per cent significance level. All the variables were statistically relevant at 1 per cent significance level with the exception of intercept (c), government expenditure (GTEXP) and exchange rate (EXCR).

The main variable of this study in the short-run, the petrol subsidy showed a positive contribution to tax revenue volatility and this is statistically relevant at 1 per cent significance level. The difference between PMS subsidy contribution to the tax revenue volatility in the short-run and long-run is very minimal. If the PMS subsidy is increased by a unit, it will lead to a $5.65 \mathrm{E}-12$ point in tax revenue volatility, though very infinitesimal but statistically significant. This finding is in tandem with the implied positions of Rueben and Randall, (2017) and World Bank, (2010) that energy prices impact tax revenue and that it has an implication on macroeconomic variables. Also, government expenditure (GTEXP) increases tax revenue 
volatility. A unit increase in government expenditure will increase tax revenue volatility by 0.09 point, and this is statistically significant at a 10 per cent significance level. The behaviour of government expenditure in the long-run and short-run to tax revenue volatility differs and moves in the opposite direction. Gross domestic savings (GDS) increased tax revenue volatility; a unit increased in GDS will increase the tax revenue volatility by 0.04 point, though minimal but statistically relevant at 1 per cent significance level. The GDS behaviour in the short-run is the same as that of long-run. Gross fixed capital formation (GFCF) reduced the tax revenue volatility equally at the short-run. A unit increase in the GFCF will reduce tax revenue volatility by 0.05 point and this is statistically relevant at 1 per cent significance level. Finally, the ECM coefficient of -1.02 and statistically significance at 1 per cent implied that any deviation in the variables' behaviour will be corrected within a year period.

\begin{tabular}{|l|c|c|c|}
\hline \multicolumn{5}{|c|}{ Table 3.5.2 Short-run and Error Correction Model Estimation } \\
\hline \multicolumn{1}{|c|}{ Variable } & Coefficient & t-statistics & Prob. \\
\hline C & -2.423464 & -0.214985 & 0.8318 \\
\hline D(PMS_SUB $)$ & $5.65 \mathrm{E}-12^{*}$ & 3.261740 & 0.0036 \\
\hline D $($ GTEXP $)$ & 0.098044 & 1.856608 & 0.0769 \\
\hline D (EXCR $)$ & 1.122293 & 0.532461 & 0.5997 \\
\hline D $($ GDS $)$ & $0.043214^{*}$ & 5.609629 & 0.0000 \\
\hline D $($ GFCF $)$ & $-0.059155^{*}$ & -5.767073 & 0.0000 \\
\hline ECM $(-1)$ & $-1.021392^{*}$ & -3.955880 & 0.0007 \\
\hline R-squared & 0.749504 \\
\hline Adj. R-squared & 0.681187 \\
\hline F-stat & $10.97097^{*}$ \\
\hline \multicolumn{4}{|l|}{ Source: Authors' computation using Eviews 10} \\
\hline
\end{tabular}

3.5.2 Stability tests for both the Long-run and the Short-run estimations

Fig. 3.5.1 and 3.5.2 showed the graphical stability test called CUSUM Test. It is based on the cumulative sum of the recursive residuals (Brown, Durbin, \& Evans, 1975). The plots showed the cumulative sum together with the 5 per cent critical lines. Since the cumulative line stays within the two critical lines, the model's parameters are said to be stable both in the long-run and short-run at the 5 per cent significance level. This implies that the coefficients of the variables in the model would be stable when compared to the expected coefficient from the projection.

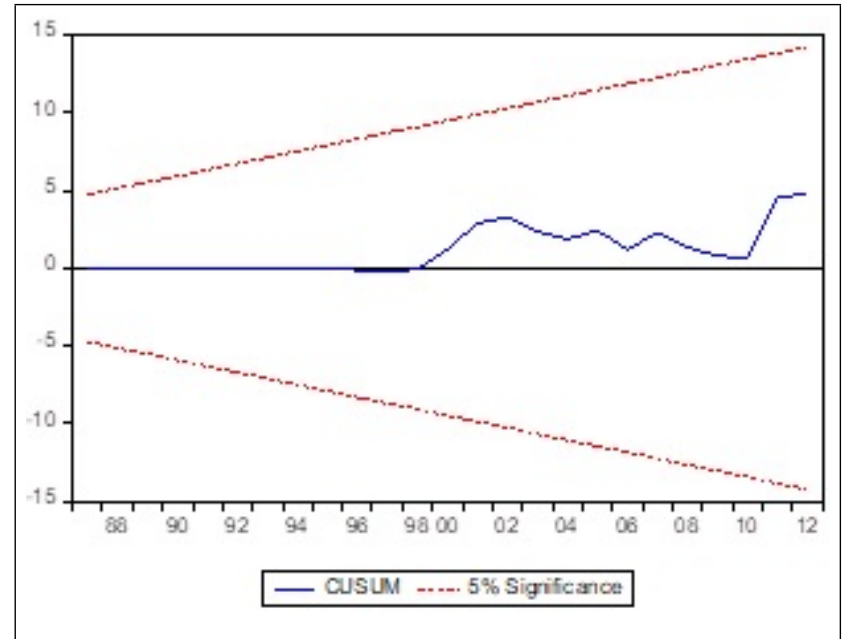

Fig. 3.5.1: Stability Graph for the Long-run Estimation 


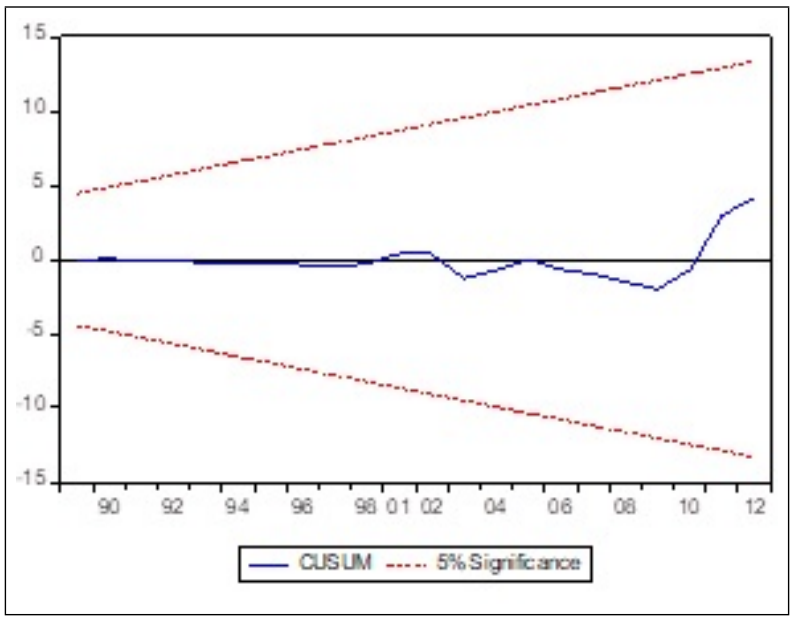

Fig. 3.5.2: Stability Graph for the Long-run Estimation

\section{CONCLUSION AND POLICY IMPLICATIONS}

This study investigated the impact of Premium Motor Spirit (PMS) subsidy on tax revenue volatility in Nigeria. It adopted ARCH and GARCH models to verify volatility in the tax revenue and uses the ordinary least squares method to evaluate the impact in both the long and short-run, together with the error correction model. This study has become the pathfinder in carrying out a fully empirical study on PMS subsidy in Nigeria because PMS subsidy dataset for Nigeria is not available but this study has calculated one, which made this study possible as well. This study will serve as the reference point for any other relevant study that may likely come up. Also, it has brought to the limelight the empirical impact of PMS subsidy and other variables on the tax revenue volatility, which has only be known theoretically before now, in the case of Nigeria. PMS subsidy contributed to tax revenue volatility in both the long-run and short-run. Although, its contribution is very minimal, however, it was statistically significant. Also, some other factors such as exchange rate and gross domestic savings contributed far more to the tax revenue volatility. Exchange rate took the lead by contributing 5.10 point in the long-run while its short-run value was insignificant. Government expenditure reduced the tax revenue volatility in the long-run but increased it in the short-run; though the short-run coefficient was not found to be statistically significant. Gross fixed capital formation behaved as expected at both the long-run and short-run, that is, it reduced tax revenue volatility at both time frame. All these variables performed in accordance with the theoretical expectations. So far, all the variables in the model behaved as expected based on the generic economic theoretical knowledge. The ECM showed that any deviation in the estimates would be restored within a year period and this is statistically significant at 1 per cent. Studies such as Rogoff and Reinhardt, (2010) and IMF, (2013) among others asserted that fuel subsidy has macroeconomic implications, while the implication on each of the macroeconomic variables is left of economic knowledge to judge the possible behaviour.

Tax revenue volatility should not be a concern for the national government in maintaining PMS subsidy. The proposition that PMS subsidy is a major cause of volatility in tax revenue is less verified empirically. The concerned governmental institution, which is saddled with the responsibility of maintaining monetary policy should work more towards a more favourable exchange rate in order to minimize tax revenue volatility. If the government must give PMS subsidy, then, it must put in place strong maintenance of its expenditure and capital investment to minimize tax revenue volatility. If not for any other reason, the national government may permit its teeming population to continue enjoying subsidy because its effect on its tax revenue volatility is not overburdened. However, it would be better if the government could identify the more impactful window of productive common goods or services that its teeming population 
could enjoy than continue with the PMS subsidy, which aid tax revenue volatility, though, minimally. It is therefore recommended that the government should do more to manage and maintain appropriate exchange rate policy and keep on improving its expenditure towards capital formation and investment in order to manage tax revenue volatility.

Acknowledgement 1. Thanks to those who had spared their time to improve this paper. Thanks to Eunice O. Gidigbi for a supportive role in reporting this work. Thanks to the authority of the Modibbo Adama University of Technology for making its presentation a reality at the 4th International Conference of Mechanical Engineering, Energy Technology and Management (IMEETMCON 2018) at the University of Ibadan, Ibadan, Nigeria. Special thanks to the anonymous reviewers who did their reviewing assignment without any prejudice.

\section{REFERENCES}

[1] Adagunodo, M. (2013). Petroleum Products Pricing Reform in Nigeria: Welfare Analysis from Household Budget Survey. International Journal of Energy Economics and Policy, 3(4), 459 - 472. Retrieved from www.econjournals.com.

[2] Adenikinju, A. (2009, January). Energy Pricing and Subsidy Reforms in Nigeria. Retrieved from Research Gate: https://www.researchgate.net/publication/267710347.

[3] Atansah, P., Khandan, M., Moss, T., Mukherjee, A., \& Richmond, J. (2017). When Do Subsidy Reforms Stick? Lessons from Iran, Nigeria, and India. Washington DC: Center for Global Development. doi:https://www.cgdev.org/publication/when-do-subsidy-reforms-stick-lessons-iran-nigeria-and-india.

[4] Brons, M., Peter, N., Eric, P., \& Piet, R. (2008). A Meta-Analysis of the Price Elasticity of Gasoline Demand: A SUR Approach. Energy Economics, 30, 2105 - 2122.

[5] Brown, R. L., Durbin, J., \& Evans, J. M. (1975). Techniques for Testing the Constancy of Regression Relationships Over Time. Journal of the Royal Statistical Society, Series B(37), 149 - 192.

[6] Coady, D., Gillingham, R., Ossowski, R., Piotrowski, J., Tareg, S., \& Tyson, J. (2010). Petroleum Product Subsidies: Costly, Inequitable, and Rising. IMF. Washington: International Monetary Fund.

[7] Davis, L. W. (2017). The Environmental Cost of Global Fuel Subsidies. The Energy Journal, 38, 7-17.

[8] Ekong, C. N., \& Akpan, U. F. (2014). Energy Subsidy Reform and Sustainable Development in Nigeria. International Journal of Management and Sustainability, 3(4), 186-202.

[9] Hamilton, L. C. (2006). Statistics with STATA: Updated for version 9. Belmont, CA: Thomson Higher Learning.

[10] IEA. (2010). World Energy Outlook 2010. Paris: International Energy Agency.

[11] IMF. (2013). Energy Subsidy Reform: Lessons and Implications. Washington DC: IMF.

[12] Inchauste, G., \& Victor, D. G. (2017). The Political Economy of Energy Subsidy Reform. In G. Inchauste, D. G. Victor, G. Inchauste, \& D. G. Victor (Eds.), Chapter 1 (pp. 17-18). Washington, DC: International Bank for Reconstruction and Development/ The World Bank. doi:10.1596/978-1-4648-1007-7.

[13] Johansen, S. (1991). Estimation and Hypothesis Testing of Cointegration Vectors in Gaussian Vector Autoregressive Models. Econometrica, 59, 1551-1580.

[14] Katz, M. L., \& Rosen, H. S. (1994). Microeconomics (2nd ed.). Sydney: Irwin.

[15] McCulloch, N., \& Okigbo-III, P. O. (2015). Fuel Subsidy Reform: Pragmatic Options for the Incoming Government. Oxford: Nextier.

[16] Parry, I. (1998). A Second_Best Analysis of Environmental Subsidies. International Tax and Public Finance, $5(2), 153-170$.

[17] Rogoff, K., \& Reinhardt, C. (2010). Growth in a Time of Debt. American Economic Review, 100(2), 573 578.

[18] Rueben, K., \& Randall, M. (2017, November). Urban Institute. Retrieved from Urban: www.urban.org.

[19] Sterner, T. (2007). Fuel Taxes: An Important Instrument for Climate Policy. Energy Policy, 35(6), 3194 3202.

[20] Umar, H. M., \& Umar, M. S. (2013). An Assessment of the Direct Welfare Impact of Fuel Subsidy Reform in Nigeria. American Journal of Economics, 3(1), 23-26. doi:10.5923/j.economics.20130301.05.

[21] World Bank. (2010). Subsidies in the Energy Sector: An Overview. Energy, Transport, and Water Department. Washington DC: World Bank Group. 


\section{Appendix}

\begin{tabular}{|c|c|c|c|c|}
\hline \multicolumn{5}{|c|}{ Dependent Variable: TRV_5 } \\
\hline \multicolumn{5}{|l|}{ Method: ML - ARCH } \\
\hline \multicolumn{5}{|c|}{ Date: 05/26/18 Time: 09:26 } \\
\hline \multicolumn{5}{|l|}{ Sample: 19812016} \\
\hline \multicolumn{5}{|c|}{ Included observations: 36} \\
\hline \multirow{2}{*}{\multicolumn{5}{|c|}{$\begin{array}{l}\text { Failure to improve Likelihood after } 51 \text { iterations } \\
\text { Presample variance: backcast (parameter }=0.7 \text { ) }\end{array}$}} \\
\hline & & & & \\
\hline \multicolumn{5}{|c|}{$\mathrm{GARCH}=\mathrm{C}(2)+\mathrm{C}(3)^{*} \mathrm{RESID}(-1)^{\wedge} 2+\mathrm{C}(4)^{*} \mathrm{GARCH}(-1)$} \\
\hline Variable & Coefficient & Std. Error & z-Statistic & Prob. \\
\hline \multirow[t]{2}{*}{ @SQRT(GARCH) } & 0.331932 & 0.118615 & 2.798397 & 0.0051 \\
\hline & \multicolumn{2}{|c|}{ Variance Equation } & & \\
\hline $\mathrm{C}$ & 2683.764 & 1435.428 & 1.869660 & 0.0615 \\
\hline $\operatorname{RESID}(-1)^{\wedge} 2$ & 1.619495 & 0.786150 & 2.060033 & 0.0394 \\
\hline GARCH(-1) & -0.251435 & 0.088978 & -2.825813 & 0.0047 \\
\hline R-squared & -0.005600 & Mean depe & endent var 3 & 93.2834 \\
\hline Adjusted R-squared & -0.005600 & S.D. depen & ndent var 4 & 146.2737 \\
\hline S.E. of regression & 447.5216 & Akaike inf & fo criterion 1 & 2.87045 \\
\hline Sum squared resid & 7009645. & Schwarz c1 & riterion & 3.04640 \\
\hline Log likelihood & -227.6681 & Hannan-Q & uinn criter. 1 & 2.93186 \\
\hline Durbin-Watson stat & 0.104499 & & & \\
\hline
\end{tabular}

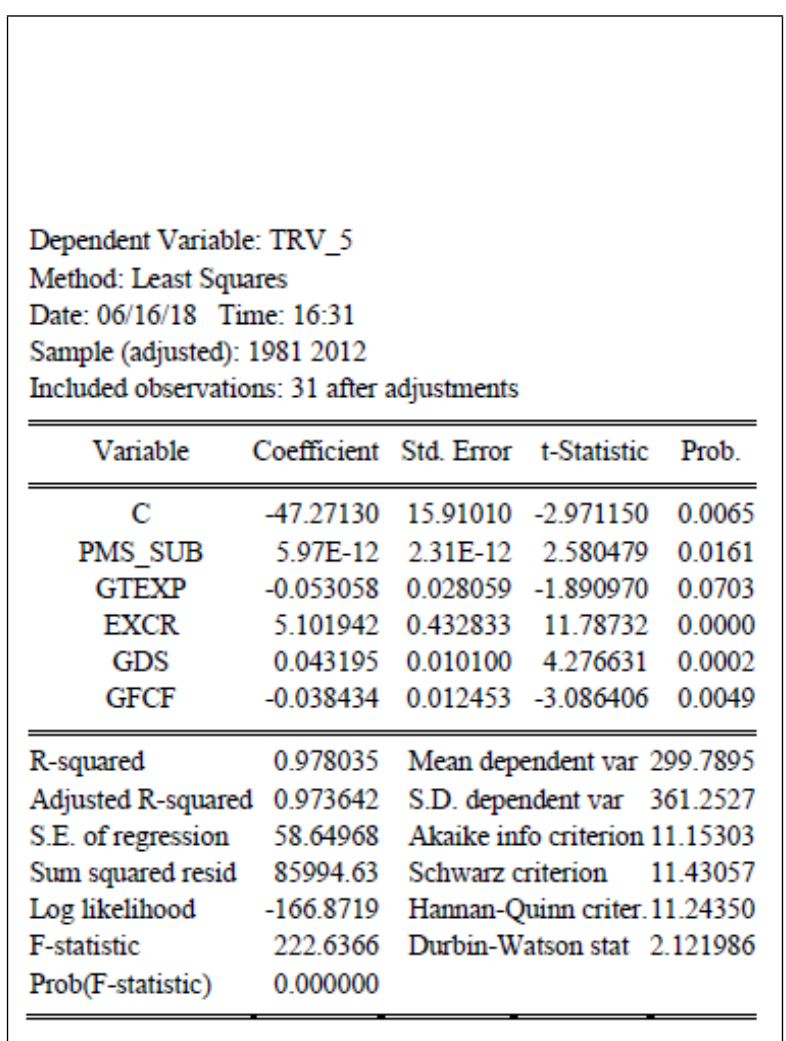




\begin{tabular}{|c|c|c|c|c|}
\hline \multicolumn{5}{|c|}{$\begin{array}{l}\text { Dependent Variable: D(TRV_5) } \\
\text { Method: Least Squares } \\
\text { Date: 05/26/18 Time: } 16: 36 \\
\text { Sample (adjusted): } 19822012 \\
\text { Included observations: } 29 \text { after adjustments }\end{array}$} \\
\hline Variable & Coefficient & Std. Error & t-Statistic & Prob. \\
\hline $\mathrm{C}$ & -2.423464 & 11.27272 & -0.214985 & 0.8318 \\
\hline D(PMS_SUB) & $5.65 \mathrm{E}-12$ & $1.73 \mathrm{E}-12$ & 3.261740 & 0.0036 \\
\hline $\mathrm{D}$ (GTEXP) & 0.098044 & 0.052825 & 1.856008 & 0.0769 \\
\hline $\mathrm{D}(\mathrm{EXCR})$ & 1.122293 & 2.107746 & 0.532461 & 0.5997 \\
\hline $\mathrm{D}(\mathrm{GDS})$ & 0.043214 & 0.007704 & 5.609629 & 0.0000 \\
\hline $\mathrm{D}(\mathrm{GFCF})$ & -0.059155 & 0.010257 & -5.767073 & 0.0000 \\
\hline $\mathrm{ECM} 03(-1)$ & -1.021392 & 0.258196 & -3.955880 & 0.0007 \\
\hline R-squared & 0.749504 & \multicolumn{3}{|c|}{ Mean dependent var 27.93915} \\
\hline Adjusted R-squared & 0.681187 & \multicolumn{3}{|c|}{ S.D. dependent var 85.81725} \\
\hline S.E. of regression & 48.45543 & \multicolumn{3}{|c|}{ Akaike info criterion 10.80567} \\
\hline Sum squared resid & 51654.43 & \multicolumn{3}{|c|}{ Schwarz criterion $\quad 11.13571$} \\
\hline Log likelihood & -149.6822 & \multicolumn{3}{|c|}{ Hannan-Quinn criter. 10.90903} \\
\hline F-statistic & 10.97097 & \multirow{2}{*}{\multicolumn{2}{|c|}{ Durbin-Watson stat }} & 1.443141 \\
\hline Prob(F-statistic) & 0.000011 & & & \\
\hline
\end{tabular}

